\title{
Kompol Yuni Dalam Pusaran Kasus Penyalahgunaan Narkoba; Sebagai Pelaku Atau Korban?
}

\author{
Ali Johardi \\ Fakultas Hukum, Universitas Bhayangkara Jakarta Raya \\ Email: ali.johardi@dsn.ubharajaya.ac.id
}

Article info

Received: Apr 19, $2021 \quad$ Revised: May 14, $2021 \quad$ Accepted: May 22, $2021 \quad$ Published: Jun 10, 2021

DOI: https://doi.org/10.31599/krtha.v15i1.596

Keywords : Legal, Social, Health, Abuse, Drugs

Abstract : Drug Abuse cases can be viewed from various dimensions, including other dimensions of Legal, Social dimension, and Health dimension. These three dimensions at one point, can be intertwined and even supporting each other. But on the side otherwise, there are very significant differences, even contradicting one another. the most striking difference, in this case, is the establishment of the status of the person using / abusing drugs. According to the bealth dimension, a drug abuser is a sick person (victim) who must be treated and rehabilitated according to health standards. But in the legal dimension, people who abuse drugs are the perpetrators of a criminal act as regulated in criminal law, especially article number 35 of 2009 concerning Narcotics which can be punished with a beavy sentence. When a drug case involving members of the national police (POLRI) perpetrated by Kompol Yuni and eleven of his subordinates at the Astana Anyar Bandung sectoral police emerged. This case can be viewed from three dimensions above, we can see that in this particular case Kompol Yuni is not only a criminal drug abuser, but also a victim of the drug abusion herself.

Kata kunci : Hukum, Sosial, Kesehatan, Penyalahgunaan, Narkoba

Abstrak : Kasus Penyalahgunaan Narkoba dapat ditinjau dari berbagai dimensi, antara lain dimensi Hukum, dimensi Sosial, dan dimensi Kesehatan. Ketiga dimensi tersebut disatu titik, memiliki keterpaduan dan saling mendukung/ menguatkan. Namun di sisi lain, terdapat perbedaan yang sangat signifikan, bahkan saling berseberangan. Sisi perbedaan yang paling mencolok adalah penetapan status orang yang menggunakan/ menyalahgunakan Narkoba, menurut dimensi kesehatan adalah orang sakit (korban) yang harus diterapi dan rehabilitasi sesuai standar kesehatan. Namun yang melihat dari dimensi Hukum, maka orang yang menyalahgunakan Narkoba adalah pelaku tindak pidana sebagaimana diatur dalam Undang Undang, khususnya Undang Undang nomor 35 tahun 2009 tentang Narkotika dengan ancaman pidana yang berat. Ketika kasus Narkoba yang melibatkan anggota Polri, yaitu Kompol Yuni dan sebelas anak buahnya di Polsek Astana Anyar Bandung, ditinjau dari ketiga dimensi diatas, maka sesungguhnya Kompol Yuni bukan hanya sebagai pelaku tindak pidana Penyalahgunaan Narkoba, namun sekaligus sebagai korban. 


\section{PENDAHULUAN}

Sebagaimana kita sadari bersama, bahwa masalah Narkoba adalah permasalahan yang sangat kompleks karena tidak saja melibatkan individu atau sekelompok orang, namun merupakan permasalahan bangsa diseluruh dunia. Tidak ada satu negarapun di dunia ini yang mengklaim bahwa negaranya " Bersih dari Narkoba" dalam artian tidak mempunyai masalah penyalahgunaan maupun peredaran gelap Narkoba. Demikian Juga kondisinya di negara kita, Indonesia tidak jauh berbeda dengan kompleksitas yang berbeda. Bahkan di Indonesia, tidak ada seorangpun pemimpin di tingkat Kecamatan berani menyatakan wilayahnya bersih dari Narkoba ${ }^{1}$.

Permasalahan Narkoba sedemikian kompleks memasuki semua kehidupan berbangsa dan bernegara, mulai dari terjadinya ketidak harmonisan kehidupan rumah tangga jika salah satu anggota keluarganya terlibat dalam penyalahgunaan Narkoba, terjadinya konflik sosial, menurunnya tingkat kesehatan masyarakat dan peningkatan terjadinya kriminalitas dari yang ringan sampai yang sangat serius sebagai dampak dari penyalahgunaan Narkoba dan peredaran gelap narkoba. Awal mula terjadinya penyalahgunaan narkoba karena adanya peredaran gelap narkoba di masyarakat. Kondisi ini dari tahun ke tahun semakin terjadi peningkatan kasus penyalahgunaan dan peredaran gelap Narkoba. yang terlibat dalam masalah ini tidak saja masyarakat biasa, bahkan juga penegak hukum yang seharusnya melaksanakan penegakkan hukum terhadap penyalahgunaan dan peredaran gelap Narkoba. Sehingga tidak berlebihan jika sejak tahun 2015 lalu Presiden RI menyatakan bahwa Indonesia Darurat Narkoba ${ }^{2}$.

Di penghujung bulan Februari 2021 yang lalu, kita tersentak dengan ramainya pemberitaan Perwira menengah Polri dengan jabatan yang bergengsi, yaitu Kapolsek Astana Anyar Polrestabes Bandung, Komisaris Polisi Yuni SP (Polwan) beserta sebelas anggotanya pesta Narkoba di kantornya! ${ }^{3}$. Hampir seminggu berbagai media memberitakan kejadian tersebut, yang mana ini menunjukkan bahwa masalah Narkoba yang melibatkan aparat Penegak Hukum khususnya Polri sangat menyita keprihatinan kita semua, tak terkecuali institusi Kepolisian RI. Hal ini dapat kita lihat dari ramainya kontroversi berbagai pernyataan baik dari masyarakat luas, pejabat, tokoh masyarakat, para pakar dan Kepala Kepolisian RI sendiri sehubungan kasus diatas ${ }^{4}$. Pada dasarnya

\footnotetext{
${ }^{1}$ Rakor Calon Bupati dan walikota se Indonesia, Balai Diklat Kemdagri, Jakarta, 2019

${ }^{2}$ https://nasional.kompas.com/read/2015/02/04/10331931/Presiden.Jokowi.Indonesia.Gawat. Darurat.Narkoba

${ }^{3}$ https:/ / www.cnnindonesia.com/nasional/20210219102002-12-608247/ironi-kompol-yunidari-kasat-narkoba-sampai-terjerumus-sabu

4 ibid
} 
semua pernyataan yang ada dalam pemberitaan tersebut menyatakan bahwa apa yang telah dilakukan Kompol Yuni dan anggotanya merupakan pelanggaran hukum, sehingga otomatis memposisikan Kompol Yuni dan anggotanya yang terlibat penyalahgunaan narkoba tersebut menyandang predikat sebagai tersangka/ pelaku tindak pidana Narkotika sebagaimana diatur dalam Undang Undang Narkotika nomor 35 tahun 2009 dan peraturan perundang undangan lain yang terkait. Statusnya sebagai anggota Polri aktif membuat kasus Kompol Yuni ini menjadi sangat unik dan mengundang kontroversi khlayaka, apalagi dikaitkan dengan institusi dimana Kompol Yuni berada, yaitu Kepolisian Negara RI yang salah satu fungsinya adalah sebagai Penegak Hukum, termasuk didalamnya melakukan penegakkan hukum terhadap Tindak pidana Narkoba. Maka, kasus Kompol Yuni ini membuat 'gerah' seluruh keluarga besar Polri, karena menyadari bahwa ulah segelintir orang oarang yaitu Kompol Yuni dan kawan kawannya, berpotensi menurunkan penghargaan dan kredibilitas Polri.

Dalam tulisan ini, penulis membahas posisi Kompol Yuni khususnya, dalam persfektif yang lain. Maksudnya, penulis ingin mencoba mengulas dari sudut pandang masalah Narkoba yang complecated, apakah Kompol Yuni murni sebagai pelaku kejahatan Narkoba, atau mungkin juga kita bisa memandang bahwa Kompol Yuni juga sebagai korban Narkoba? Tentu pembahasan dari sudut pandang ini tidak hanya ditinjau dari dimensi hukum, walaupun Pasal 54 UU no.35/ 2009 tentang Narotika, secara eksplisit ada menyebutkan tentang:"......korban penyalahgunaan Narkotika..." Penulis mencoba menelaah dalam dimensi lain, yaitu dimensi sosial dan dimensi kesehatan. Menurut penulis hal ini memungkinkan, mengingat Permasalahan Narkoba adalah termasuk Kejahatan tanpa korban (Crime without Victim). Penulis berharap dengan belajar dari kasus yang menimpa Kompol Yuni ini, kita dapat menambah pemahaman tentang permasalahan Narkoba yang begitu bervariasi dan kompleks.

\section{METODE PENELITIAN}

Metode yang digunakan dalam penelitian ini adalah dengan pendekatan yuridis normatif yaitu dengan melakukan penelitian berdasarkan pada bahan-bahan hukum/referensi dengan cara menelaah teori-teori dan konsep-konsep dari bahan-bahan hukum tersebut, yang berkaitan dengan asas-asas hukum peraturan perundang-undangan yang berhubungan dengan penulisan/penelitian ini. 


\section{PEMBAHASAN}

\section{Tinjauan kasus Penyalahgunaan Narkoba}

\section{Dimensi Hukum}

Ditinjau dari dimensi hukum, sebagaimana penulis telah kemukakan diatas, jelas Kompol Yuni berstatus tersangka tindak pidana penyalahgunaan (peredaran gelap?) Narkoba. Penyidik dan Propam Polda Jawa Barat beserta tim Mabes Polri masih bekerja keras mendalami kasus Kompol Yuni ini, apakah dia murni sebagai pengguna (penyalahgunaan) Narkoba, atau sekaligus sebagai pelaku peredaran gelap Narkoba sebagaimana diduga oleh berbagai kalangan. Dalam ketentuan yang diatur Undang Undang nomor 35 tahun 2009 tentang Tindak pidana Narkotika, ada pasal yang mengatur sanksi hukuman bagi Penyalahguna (pengguna) narkoba dan ketentuan yang mengatur sanksi bagi pelaku peredaran gelap Narkoba termasuk, produsen, pemasok, kurir, dan pengedar Narkotika secara ilegal, dengan ancaman hukuman yang sangat berat yaitu hukuman mati dan denda yang sangat besar 5 . Dalam dimensi ini status Kompol Yuni adalah tersangka pelaku kejahatan Narkoba dengan ancaman hukuman pidana.

Yang menarik dalam Undang undang nomor 35 tahun 2009 tentang narkotika ini, ada istilah Korban penyalahgunaan narkotika (pasal 54). Bagi penyandang status ini, maka tetap dikenakan sanksi hukuman berdasarkan keputusan hakim yang berkekuatan tetap, yaitu hukuman dalam bentuk Rehabilitasi. Jadi secara eksplisit, Undang Undang ini mengakui adanya "korban" penyalahgunaan Narkotika. Yang menjadi permasalahan substansial sampai saat ini, terutama dikalangan penegak hukum adalah bagaimana menentukan definisi dan kriteria status Penyalahguna atau korban penyalahguna, dan pecandu Narkoba? Dari proses penegakkan Hukum, dan disebut dalam Undang Undang, bahwa setiap orang yang "memiliki dan atau menguasai" Narkoba, masuk kategori perbuatan pidana yaitu sebagai tersangka.

Peraturan Menteri kesehatan (Permenkes) nomor 4 tahun 2020 tentang Penyelenggaraan Institusi Penerima Wajib Lapor, mengatur secra sistematis dan terinci tentang penanganan terhadap orang yang menyalahgunakan Narkoba, korban penyalahgunaan dan pecandu narkoba. Perlakuan yang diberikan sesuai standar penanganan terhadap pasien atau orang sakit yang perlu direhabilitasi. Secara implisit, Permenkes ini mengisyaratkan bahwa orang yang bermasalah dengan penyalahgunaan narkoba adalah merupakan korban. Untuk itulah salah satu implementasi dari Permenkes

${ }^{5}$ https://www.hukumonline.com/pusatdata/detail/lt4af3b7f6cf607/undangundang-nomor-35tahun-2009/document 
tersebut diatas adalah terbentuknya Institusi Penerima Wajib Lapor (IPWL) bagi pengguna dan atau pecandu Narkoba yang tersebar di sebagian Puskesmas dan Rumah Sakit Umum Daerah di tanah air. Orang yang sudah dengan sukarela melapor ke IPWL, tidak dapat dikenakan sanksi pidana, kecuali yang bersangkutan juga berprofesi ganda sebagai pengedar gelap Narkoba. Perangkat peraturan perundang undangan di Indonesia tentang Narkoba baik secara eksplisit maupun implisit mengatur tentang orang yang "banya" menyalahgunakan Narkoba diposisikan sebagai korban. Hal ini juga diatur dalam konvensi PBB tahun 1988 tentang Narkoba ${ }^{6}$ yang telah diratifikasi oleh Indonesia.

\section{Dimensi Sosial}

Kita ketahui bersama, bahwa pemberitaan tentang keterlibatan Kompol Yuni dalam penyalahgunaan Narkoba mewarnai sebagian besar pemberitaan media, baik cetak maupun media sosial dengan berbagai tanggapan dari kalangan masyarakat termasuk para tokoh dan anggota DPR. Dalam pemberitaan tersebut topik yang diulas ternyata tidak saja seputar bagaimana kasus penyalahgunaan Narkoba yang dilakukan Kompol Yuni dan anggotanya, namun juga sisi lain dari kehidupan Kompol Yuni yang ikut menjadi bagian dari berita tersebut, termasuk kehidupan pribadinya antara lain kehidupan Kompol Yuni yang berperan ganda sebagai orang bagi anak anaknya (single parent), jumlah kekayaan dan juga hutangnya. Disadari atau tidak, pengungkapan sisi pribadi ini akan mempengaruhi kehidupan dan interaksi sosial Kompol Yuni dan keluarga besarnya, baik hubungan dengan anak anaknya yang tentu sangat terpukul dengan pemberitaan orang tua mereka yang selama ini menjadi tulang punggung keluarga, maupun hubungan sosialnya dengan saudara, handai toulan dan lingkungan masyarakat sekitarnya. Paling tidak sudah ada stigma negatif terhadap interaksi sosial, berkurangnya rasa kepercayaan dan sikap menghargai seperti sebelumnya terhadap Kompol Yuni dan keluarganya. Dengan demikian, sudah terjadi "vonis sosial" terhadap Kompol Yuni sebelum kasusnya tuntas secara proses hukum dan mempunyai kekuatan hukum yang tetap. Sehingga patut diduga Kompol Yuni maupun keluarganya akan mengalami depresi serius dengan keadaan semacam ini. Situasi ini disatu sisi, mungkin bisa menimbulkan efek jera dan penyesalan mendalam atas perbuatan yang telah dilakukannya. namun tidak menutup kemungkinan yang terjadi justru sebaliknya, yaitu rasa depresi yang dialami Kompol Yuni justru semakin menjerumuskan dirinya atau bahkan anggota keluarganya kedalam penyalahgunaan dan atau peredaran gelap Narkoba. Bila kita tinjau dari dimensi sosial ini, kiranya tidak

${ }^{6}$ https://www.unodc.org/pdf/convention_1988_en.pdf 
berlebihan jika Kompol Yuni kita kategorikan merupakan korban. dari keganasan pengaruh negatif Narkoba yang mengganggu sistem saraf dan perilaku dirinya sendiri, yang juga membawa akibat lanjutan bagi anggota keluarganya dari aspek sosial yang dialaminya.

Dari aspek perbuatannya, yaitu menyalahgunakan Narkoba, kita mengingat kembali teori konvensional tentang terjadinya kejabatan, yaitu bertemunya niat dan kesempatan (Kejahatan=Niat+Kesempatan). Menurut saya teori ini relevan untuk menggambarkan kasus yang dialami Kompol Yuni. Dalam berbagai pemberitaan media dibeberkan juga kiprah gemilang Kompol Yuni dalam memberangus peredaran gelap Narkoba sehingga karirnya menanjak dan terkenal sebagai aparat penegak hukum yang selalu sukse dalam mengungkap berbagai kejahatan Narkoba. Selama perjalanan tugasnya sebagai penegak hukum diatas, Kompol Yuni pasti sangat sering berinteraksi dengan orang yang terkena masalah Narkoba, dan Narkoba itu sendiri sebagai barang bukti. Kondisi ini memberikan kemudahan bagi Kompol Yuni bersentuhan langsung dengan barang bukti Narkoba yang ada dalam penguasaannya. Kondisi ini lama kelamaan menimbulkan niat ingin mencoba seperti apa rasanya menggunakan Narkoba. Dari mencoba itulah kemudian menjadi ketagihan karena Narkoba memiliki daya ketergantungan (Addict) yang tinggi. Sehingga pada akhirnya Kompol Yuni dan seperti orang pengguna Narkoba lainnya, menjadi budak ketergantungan Narkoba dengan mengabaikan segala resiko serta akibat buruk yang ditimbulkannya. Dengan telaahan diatas, maka Kompol Yuni adalah korban dari daya pikat dan daya ketergantungan dari Narkoba. Dengan mempertimbangkan kondisi diatas, maka Kementerian Sosial mengimplementasikan program Rehabilitasi Sosial bagi pengguna Napza (Narkotika, Psikotropika, dan Zat Adiktif) atau istilah lain dari Narkoba. Dari program ini, dapat dipahami bahwa dari aspek sosial, para pengguna atau penyalahguna Narkoba/ Napza digolongkan sebagai korban yang harus ditolong untuk kembali sembuh dari ketergantungan terhadap narkoba, dengan tidak dikenakan sanksi hukuman (pidana).

\section{Dimensi Kesehatan}

Dari sudut pandang kesehatan, banyak literatur yang mengkategorikan orang yang menyalahgunakan dan ketergantungan terhadap Narkoba, adalah orang yang sakit yang harus diobati (Rehabilitasi) dengan metode dan penanganan yang khusus, karena orang yang menggunakan Narkoba tidak merasa bahwa dirinya sakit dan tidak mampu menyembuhkan sakitnya tanpa bantuan tenaga medis. Peran keluarga (orang terdekat), 
lingkungan sosial sekitar dan ahli kejiwaan juga berperan dalam proses penyembuhan orang yang ketergantungan Narkoba. Penangannya harus terpadu, komprehensif, menyeluruh dan tuntas secara sistematis. Proses rehabilitasi yang tidak tuntas atau dilakukan asal saja, tidak akan memberikan hasil kesembuhan yang optimal. Setelah proses rehabilitasi selesai pun, masih harus diikuti dengan program pemulihan yaitu program pasca rehabilitasi (Aftercare $)^{7}$. Walaupun kedua program diatas sudah dilakukan secara benar dan tuntas, tidak menjamin seratus persen bahwa si pengguna tersebut tidak akan mengulangi perbuatannya. Situasi dan kondisi tertentu yang tidak sama bagi setiap orang, bisa memicu mantan pengguna/ pecandu Narkoba mengulang kembali perbuatannya, demikian seterusnya tanpa berkesudahan. Banyak contoh kejadian mantan pengguna atau pecandu Narkoba yang sudah diproses hukum dan dihukum, masih mengulangi perbuatannya setelah bebas, seperti Tessy (anggota pelawak Srimulat) dan artis lainnya.

Proses rehabilitasi yang begitu panjang dan kompleks, ternyata terbukti tidak bisa memulihkan seratus persen kondisi pengguna/ pecandu Narkoba sembuh seperti sedia kala. Demikian kuat daya ketergantungan narkoba mencengkeram saraf otak pemakainya sehingga menghancurkan masa depan dan kehidupan mereka sendiri, dan menyengsarakan keluarga serta orang disekitar mereka. Sesungguhnya mereka adalah korban dari ganasnya Narkoba, tak terkecuali Kompol Yuni yang juga manusia biasa seperti yang lainnya. Narkoba tidak pandang status sosial, jenis kelamin, pangkat maupun jabatan korbannya, maka itu kejahatan Narkoba merupakan kejahatan yang Extra Ordinary Crime. Namun tidak demikian jika dikaji dari dimensi kesehatan, pengguna Narkoba dikategorikan sebagai orang sakit yang terganggu mentalnya, dan perlu diterapi dengan rehabilitasi khusus, walaupun hasilnya tidak seratus persen kembali pulih seperti sebelumnya. Dari hasil penelitian kesehatan, pengguna Narkoba mengalami berbagai gangguan kesehatan baik fisik maupun psikis dari yang ringan sampai berat, yaitu antara lain: sering kejang, lemah, agresif, sensitif, bahkan sampai kematian. Hali ini karena Narkoba, misalnya jenis Ganja (Cannabis Sativa), penggunaan yang sering akan menyebabkan otak mengalami penyusutan ${ }^{8}$. Bila otak sebagai pusat pengendali saraf manusia mengalami penyusutan, maka terjadi kerusakan atau difungsional saraf, sehingga menyebabkan berbagai gangguan fisik maupun psikis. Demikian juga Narkoba jenis lainnya, masing masing memberikan dampak negatif bagi kesehatan tubuh manusia dengan daya ketergantungan yang signifikan. Adanya fenomena Narkotika jenis baru

\footnotetext{
${ }^{7}$ https://www.rehabs.com/addiction/aftercare-programs-drug-recovery/

8 Jurnal Penelitian Kesehatan
} 
(New Psychoactive Subtances-NPS) yang mulai meluas pada tahun 2000 lalu, semakin menambah beban kesehatan masyarakat dan beban sosial secara global, sebagai akibat yang ditimbulkan penyalahgunaan dan peredaran gelap NPS dimaksud. Penegak Hukum juga semakin sulit untuk mendeteksi dan mengidentifikasi NPS, karena bahan bahan dasarnya banyak tersebar dan mudah diperoleh dengan harga terjangkau (murah) dibandingkan jenis Narkotika yang konvensional (Methapetamin, Ganja, Kokain). Contoh dari beberapa NPS yang berhasil diungkap adalah: tembakau Gorilla, Pil PCC, Sabu (meth) cair, dan sebagainya.

\section{KESIMPULAN}

Pada bagian akhir dari tulisan yang mengulas tentang status kompol Yuni baik dari dimensi Hukum, Sosial, maupun dimensi kesehatan, penulis ingin merekomendasikan beberapahal sehubungan penanganan terhadap kasus penyalahgunaan narkoba yang dilakukan kompol, Yuni maupun orang lain yang serupa, yaitu:

Institusi baik Negara maupun swasta memiliki satu pemahaman dan satu visi, bahwa pengguna Narkoba atau korban penyalahguna Narkoba adalah korban dari keganasan Narkoba. Kemudian diimplementasikan secara terpadu dengan Badan Narkotika Nasional beserta Kementerian terkait (Kemenkes dan Kemensos) dan Stake Holders lainnya. Sehingga gerakan Pencegahan dan Pemberantasan Penyalahgunaan dan Peredaran Gelap Narkoba (P4GN) menjadi suatu gerakan Nasional yang terpadu, Sistematis, dan optimal.

Mengimplementasikan kembali Peraturan Bersama (PERBER) nomor 01 tahun 2014 tentang Penanganan Pecandu Narkotika dan Penyalahgunaan narkotika ke dalam Lembaga Rehabilitasi; yang telah disepakati bersama oleh Mahkamah Agung RI, Kementerian Hukum \& HAM RI, Kementerian Kesehatan RI, Kementerian Sosial RI, Kejaksaan Agung RI, Kepolisian RI dan Badan Narkotika Nasional, yaitu adanya Tim Asesmen Terpadu (TAT) dalam penanganan awal (asessesment) terhadap orang yang ditangkap karena kasus Narkoba untuk menentukan statusnya apakah sebagai korban penyalahgunaan, penyalahguna, ataukah bagian dari sindikat peredaran gelap Narkoba. Disitu juga diatur klasifikasi tentang pecandu ringan, pecandu sedang, dan pecandu berat. Hasil rekomendasi dari TAT ini yang dijadikan pedoman oleh penegak hukum (penyidik, Penuntut, dan majelis hakim) untuk menetapkan status bagi seseorang yang diduga melakukan tindak pidana Narkoba, yang berkorelasi langsung terhadap hukuman yang dijatuhkan, apakah dalam bentuk rehabilitasi (bagi penyalahguna ddan pecandu) atau 
dalam bentuk pidana kurungan bahkan pidana mati bagi kategori sindikat peredaran gelap narkoba.

Penjabaran lebih jauh dari Peraturan Bersama sebagaimana diatas, telah ditindak lanjuti oleh Mahkamah Agung dengan terbitnya Surat Edaran mahkamah Agung RI (SEMA) nomor 4 tahun 2010 tentang Penempatan Penyalahguna, korban Penyalahgunaan dan Pecandu Narkotika; dan SEMA nomor 3 tahun 2011 tentang Penempatan korban penyalahgunaan narkotika ke dalam Lembaga Rehabilitasi Medis dan Rehabilitasi Sosial. Di dalam SEMA ini juga mengatur tentang toleransi jumlah barang bukti yang dimiliki tersangka ketika ditangkap.

Kejaksaan Agung RI juga telah menerbitkan Surat Edaran Jaksa Agung RI (SEJA) nomor: SE-002/A/JA/02/2013 tanggal 15 Pebruari tahun 2013 tentang Penempatan korban penyalahgunaan narkotika ke dalam Lembaga Rehabilitasi Medis dan Rehabilitasi Sosial. Diharapkan SEMA DAN SEJA diatas dapat menjadi pedoman dan bahan pertimbangan bagi majelis hakim dalam memutus perkara dan memberikan hukuman kasus penyalahgunaan Narkoba seperti kasus Kompol Yuni yang menghebohkan dengan adil dan sesuai kaidah kaidah hukum yang berlaku dengan mempertimbangkan dimensi Kesehatan dan dimensi Sosial sebagaimana diulas diatas.

Semoga tulisan yang jauh dari sempurna ini bisa sekedar menambah wawasan pembacanya dan semoga pula penanganan terhadap masalah Narkoba di tanah air tercinta ini menemukan formula yang tepat, efektif, efisien dan berkesinambungan, sehingga persoalan Narkoba di negara ini dapat diputus mata rantainya dengan metoda Supply and Demand Reduction, sehingga dapat menyelamatkan generasi muda bangsa Indonesia dari bencana Lost Generation sebagai akibat Narkoba. Dan semoga tulisan ini juga dapat memberikan proses hukum dan keadilan bagi Kompol Yuni dan kawan kawannya secara tepat, prosedural, proposional dan berkeadilan bagi masyarakat.

\section{DAFTAR PUSTAKA}

https://www.cnnindonesia.com/nasional/20210219102002-12-608247/ironi-kompolyuni-dari-kasat-narkoba-sampai-terjerumus-sabu

https://www.hukumonline.com/pusatdata/detail/lt4af3b7f6cf607/undangundangnomor-35-tahun-2009/document

https://nasional.kompas.com/read/2015/02/04/10331931/Presiden.Jokowi.Indonesia. Gawat.Darurat.Narkoba 
https://www.unodc.org/pdf/convention 1988 en.pdf

https://www.rehabs.com/addiction/aftercare-programs-drug-recovery/ 